\title{
Microbiology of chronic maxillary sinusitis: comparison between specimens obtained by sinus endoscopy and by surgical drainage
}

\author{
I. BROOK, E. H. FRAZIER and P. A. FOOTE* \\ Departments of Pediatrics and Infectious Diseases, Naval Hospital, Bethesda, MD and *Department of \\ Otolaryngology, Alachua General and North Florida Regional Hospitals, Gainesville, FL, USA
}

\begin{abstract}
The aerobic and anaerobic microbiology of sinus aspirates obtained during surgery was compared with culture of samples obtained by endoscopy. Six patients with chronic maxillary sinusitis were evaluated. Polymicrobial flora was found in all specimens (twoto-five isolates/sample). A total of 24 isolates (18 anaerobic, five aerobic and one microaerophilic) was obtained from sinus aspirates, and 25 isolates (16 anaerobic and nine aerobic) were found in endoscopic specimens. The predominant organisms were Prevotella spp., Fusobacterium nucleatum, Peptostreptococcus spp. and Staphylococcus spp. Concordance in the type and concentration of organisms was found in all cases. Sixteen of the 18 anaerobes isolated from sinus aspirates were also found in the concomitant endoscopic sample. Five aerobic isolates were found in both sinus aspirates and endoscopic samples and their concentration was similar. However, four aerobic gram-positive bacteria ( $<10^{4} \mathrm{cfu} / \mathrm{sample}$ ) were found only in endoscopy samples. This pilot study demonstrates the usefulness of endoscopic aspiration in the isolation of bacteria from chronically infected maxillary sinuses.
\end{abstract}

\section{Introduction}

Aspiration of the maxillary sinus during an aseptic surgical procedure or by antral puncture is considered to provide the optimal culture material for determination of the microbiology of sinusitis [1-5]. However, aspiration of the sinus is an invasive procedure that requires local or general anaesthesia, and can be associated with discomfort, pain and complications. The diagnostic and therapeutic use of endoscopy has increased in recent years [6]. However, as the procedure involves passage of the endoscope thorough the nose, the specimens obtained by endoscopy may contain organisms that originate from the nasal mucosal flora and not the involved sinus. The adequacy of sinus cultures obtained by endoscopy has therefore been questioned.

The increasing resistance to antibiotics of organisms from sinus infections has made the management of these infections more complex [7]. Sinus aspiration is used in many instances to provide guidance for the selection of

Received 11 June 1996; revised version accepted 10 Oct. 1996.

Address for correspondence: Professor I. Brook, Post Box 70412, Chevy Chase MD 20813-0412, USA. appropriate antimicrobial therapy. This pilot study was designed to compare the microbiology of sinus secretions that were obtained by endoscopy with those obtained by aspiration during surgical drainage.

\section{Patients and methods}

The six patients presented in this report were seen consecutively. All underwent a Caldwell-Luc operation for chronic maxillary sinusitis. Chronic sinusitis was judged to be present if the roentgenographic studies showed mucosal thickening and either an air-fluid level or complete opacity the maxillary sinus. All patients had tenderness over the maxillary sinus. Occipitomental (Waters' view), lateral, oblique and verticomental views were obtained. The degree of mucosal thickening was evaluated by noting the nearest distance between the air-mucosal interface and the lateral part of the sinus wall. Mucosal thickening was defined as a mucosal width of $\geqslant 6 \mathrm{~mm}$. Patients had at least two of these symptoms: facial pain, frontal headache, cough, purulent nasal discharge or fever. None of the patients had received local or systemic antimicrobial therapy for at least 1 week before sample collection. The disease was of at least 3 weeks' duration. 
Two specimens were obtained from each patient. One specimen was obtained before the Caldwell-Luc operation, by maxillary sinus endoscopy, while the patient was under general anaesthesia. The sinus secretions were collected on calcium alginate-tipped micro-swabs (CalgiFyber ${ }^{\mathrm{R}}$, MicroPur swabs ${ }^{\mathrm{TM}}$, Pur Fyber Inc, Munster, IN, USA). The swab was immediately transported to the microbiology laboratory, where it was placed in $1 \mathrm{ml}$ of pre-reduced saline and shaken vigorously for $2 \mathrm{~min}$. The second specimen was collected by aspiration during surgery, employing strict asepsis to avoid any contamination. The aspirated material was transported immediately to the microbiology laboratory in a corked syringe.

Both specimens were serially diluted in pre-reduced saline and inoculated on to media supportive of aerobic and anaerobic organisms for quantitative and qualitative studies. The time between specimen collection and inoculation never exceeded $30 \mathrm{~min}$. For aerobic bacteria, the specimens were inoculated on to sheep blood, chocolate and MacConkey's agar plates that were incubated at $37^{\circ} \mathrm{C}$ aerobically (MacConkey's agar) or in air with $\mathrm{CO}_{2} 5 \%$ (blood and chocolate agars), and examined at 24 and $48 \mathrm{~h}$. For anaerobic bacteria, the material was plated on to a pre-reduced vitamin $\mathrm{K}_{1}$-enriched Brucella blood agar plate, a blood agar plate containing kanamycin sulphate and vancomycin hydrochloride, a blood plate containing colistin and nalidixic acid, and into enriched thioglycolate broth [8]. The plates were incubated in anaerobic jars and examined at 48, 96 and $120 \mathrm{~h}$. The thioglycolate broth was incubated for
14 days. Aerobic and anaerobic bacteria were identified by previously described techniques $[8,9]$. Gram's stain preparations were made of all specimens. $\beta$-Lactamase activity was determined on all isolates by the cefinase method [10].

\section{Results and discussion}

All six sinus aspirates and endoscopy specimens showed bacterial growth. A total of 24 isolates (18 anaerobic, five aerobic and one microaerophilic) was obtained from sinus aspirates; 25 isolates (16 anaerobic and nine aerobic) were obtained from endoscopic specimens (Table 1). Anaerobic bacteria were isolated from all specimens. Aerobic bacteria were found in four of the six sinus aspirates and in all six endoscopic specimens. Polymicrobial flora was found in all specimens, with the number of isolates/specimen ranging from two to five (Table 1). The predominant anaerobic organisms were Prevotella spp. (13 isolates), Peptostreptococcus spp. (11) and Fusobacterium nucleatum (6). The predominant aerobic organisms were Staphylococcus spp. (5), Haemophilus influenzae (2), Streptococcus pneumoniae (2), and Str. pyogenes (2). $\beta$ Lactamase-producing-organisms were isolated from aspirates from five of the six patients (Table 1). Gram's stain preparations of all aspirates showed organisms similar to those isolated by culture in all instances.

The number of most aerobic and anaerobic organisms that were isolated by both methods was $\geqslant 10^{4} \mathrm{cfu} / \mathrm{ml}$. Concordance in the types and generally in the number

Table 1. Microbiology of sinus aspirates obtained from six patients with chronic maxillary sinusitis by either direct or endoscopic sampling

\begin{tabular}{|c|c|c|c|c|c|}
\hline \multirow{2}{*}{$\begin{array}{l}\text { Patient } \\
\text { no. }\end{array}$} & \multirow{2}{*}{$\begin{array}{l}\text { Age } \\
\text { (years)/ } \\
\text { sex }\end{array}$} & \multicolumn{2}{|l|}{ Sinus aspirates } & \multicolumn{2}{|l|}{ Endoscopic samples } \\
\hline & & Bacteria isolated $(\mathrm{cfu} / \mathrm{ml})$ & Gram's stain & Bacteria isolated $(\mathrm{cfu} / \mathrm{ml})$ & Gram's stain \\
\hline 1 & $36 / \mathrm{M}$ & $\begin{array}{l}\text { H. influenzae }\left(4 \times 10^{6}\right)^{*} \\
\text { F. nucleatum }\left(2 \times 10^{6}\right)^{*} \\
\text { Pstr. magnus }\left(6 \times 10^{6}\right) \\
\text { Peptostreptococcus } \mathrm{sp} .\left(10^{5}\right)\end{array}$ & $\begin{array}{l}\text { GNR } \\
\text { FGNR } \\
\text { GPC }\end{array}$ & $\begin{array}{l}H . \text { influenzae }\left(4 \times 10^{6}\right)^{*} \\
F . \text { nucleatum }\left(5 \times 10^{4}\right)^{*} \\
\text { Pstr. magnus }\left(2 \times 10^{6}\right) \\
\text { Peptostreptococcus sp. }\left(10^{5}\right)\end{array}$ & $\begin{array}{l}\text { GNR } \\
\text { FGNR } \\
\text { GPC }\end{array}$ \\
\hline 2 & $44 / F$ & $\begin{array}{l}\text { P. melaninogenica }\left(3 \times 10^{5}\right)^{*} \\
P \text {. oralis }\left(7 \times 10^{4}\right) \\
\text { Str. pneumoniae }\left(3 \times 10^{6}\right) \\
\text { a-Haemolytic streptococci }\left(10^{5}\right) \\
\text { Str. sanguis }\left(3 \times 10^{6}\right)\end{array}$ & $\begin{array}{l}\text { GNR } \\
\text { GPC }\end{array}$ & $\begin{array}{l}\text { P. melaninogenica }\left(3 \times 10^{5}\right)^{*} \\
P \text {. oralis }\left(4 \times 10^{4}\right) \\
\text { Str. pneumoniae }\left(2 \times 10^{6}\right) \\
\alpha \text {-Haemolytic streptococci }\left(6 \times 10^{4}\right) \\
\text { Non-haemolytic streptococci }\left(7 \times 10^{5}\right)\end{array}$ & $\begin{array}{l}\text { GNR } \\
\text { GPC }\end{array}$ \\
\hline 3 & $31 / \mathrm{M}$ & $\begin{array}{l}P . \text { intermedia }\left(5 \times 10^{6}\right) \\
F \text { nucleatum }\left(2 \times 10^{6}\right) \\
\text { Pstr. anaerobius }\left(4 \times 10^{5}\right) \\
\text { Pstr. micros }\left(6 \times 10^{6}\right) \\
S . \text { aureus }\left(5 \times 10^{5}\right)^{*}\end{array}$ & $\begin{array}{l}\text { GNR } \\
\text { FGNR } \\
\text { GPC }\end{array}$ & $\begin{array}{l}P . \text { intermedia }\left(9 \times 10^{5}\right) \\
F . \text { nucleatum }\left(8 \times 10^{6}\right) \\
\text { Pstr. micros }\left(6 \times 10^{4}\right) \\
S . \text { epidermidis }\left(3 \times 10^{3}\right) \\
S . \text { aureus }\left(4 \times 10^{6}\right)^{*}\end{array}$ & $\begin{array}{l}\text { GNR } \\
\text { FGNR } \\
\text { GPC }\end{array}$ \\
\hline 4 & $25 / \mathrm{F}$ & $\begin{array}{l}\text { F. nucleatum }\left(7 \times 10^{6}\right)^{*} \\
\text { Pstr. magnus }\left(8 \times 10^{6}\right) \\
\text { Veillonella parvula }\left(10^{6}\right) \\
P \text {. intermedia }\left(9 \times 10^{5}\right)\end{array}$ & $\begin{array}{l}\text { GNR } \\
\text { GPC } \\
\text { GNC } \\
\text { FGNR }\end{array}$ & $\begin{array}{l}\text { F. nucleatum }\left(4 \times 10^{7}\right)^{*} \\
\text { Pstr. magnus }\left(5 \times 10^{5}\right) \\
\text { Veillonella parvula }\left(6 \times 10^{5}\right) \\
S . \text { aureus }\left(3 \times 10^{2}\right)^{*}\end{array}$ & $\begin{array}{l}\text { GNR } \\
\text { FGNR } \\
\text { GPC } \\
\text { GNC }\end{array}$ \\
\hline 5 & $29 / \mathrm{M}$ & $\begin{array}{l}\text { P. melaninogenica }\left(10^{6}\right) \\
\text { Pstr. magnus }\left(6 \times 10^{4}\right) \\
\text { Propionibacterium acnes }\left(5 \times 10^{6}\right) \\
\text { Str. pyogenes }\left(6 \times 10^{5}\right)\end{array}$ & $\begin{array}{l}\text { GNR } \\
\text { GPC }\end{array}$ & $\begin{array}{l}\text { P. melaninogenica }\left(2 \times 10^{6}\right) \\
\text { Pstr. magnus }\left(4 \times 10^{4}\right) \\
\text { Prop. acnes }\left(3 \times 10^{6}\right) \\
\text { Str. pyogenes }\left(9 \times 10^{6}\right)\end{array}$ & $\begin{array}{l}\text { GNR } \\
\text { GPC }\end{array}$ \\
\hline 6 & $30 / \mathrm{M}$ & $\begin{array}{l}\text { P. intermedia }\left(2 \times 10^{7}\right)^{*} \\
P . \text { melaninogenica }\left(3 \times 10^{6}\right)^{*}\end{array}$ & GNR & $\begin{array}{l}\text { P. intermedia }\left(8 \times 10^{6}\right)^{*} \\
P . \text { melaninogenica }\left(6 \times 10^{6}\right)^{*} \\
S . \text { epidermidis }\left(2 \times 10^{3}\right)\end{array}$ & GNR \\
\hline
\end{tabular}


of organisms $/ \mathrm{ml}$ was found in all instances. Sixteen of 18 anaerobes isolated from sinus aspirates were also found in the concomitant endoscopic sample. The only two anaerobic isolates that were not also found in the concomitant endoscopic specimens were Pstr. anaerobius (patient no. 3) and P. intermedia (patient no. 4). The micro-aerophilic streptococci (Str. sanguis) found in a sinus aspirate (no. 2) was also not isolated in the concomitant endoscopic sample. Five aerobic organisms that were found in sinus aspirates were also cultured from the corresponding endoscopic sample in similar numbers per sample. However, four grampositive aerobic organisms (in numbers $<10^{4} \mathrm{cfu} / \mathrm{ml}$ ) were found only in the endoscopic samples (patients nos. 2, 3, 4 and 6).

This report confirms previous studies that illustrated the polymicrobial aerobic-anaerobic flora of chronically infected maxillary sinuses [1-5]. This study also demonstrated the usefulness and general accuracy of endoscopic samples in the isolation of organisms from chronically infected maxillary sinuses. The microorganisms that were found in both locations were generally found in numbers $>10^{5} \mathrm{cfu} / \mathrm{ml}$. In contrast, the isolates that were found only in endoscopically obtained specimens were generally present in numbers $<10^{4} \mathrm{cfu} / \mathrm{ml}$ (except in patient no. 2). These findings suggest that the origin of the latter isolates was the nasal mucosa rather than the sinus cavity.

This pilot study indicates the usefulness of endoscopy in establishing the microbiology of chronically infected maxillary sinuses. Quantitative cultures can exclude aerobic organisms in concentrations of $<10^{4} \mathrm{cfu} / \mathrm{ml}$ while the recovery of anaerobic bacteria even in smaller concentrations may be significant.
However, studies of larger numbers of patients are warranted to further elucidate the usefulness and limitations of bacterial cultures obtained through endoscopy in acute and chronic maxillary sinus infections.

The authors acknowledge the secretarial assistance of Joanie Pietrafitta. The opinions and assertions contained herein are the private ones of the authors and are not to be construed as official or reflecting the views of the USA Navy Department or the USA Naval Service at large.

\section{References}

1. Frederick $J$, Braude AI. Anaerobic infection of the paranasal sinuses. $N$ Engl J Med 1974; 290: 135-137.

2. Jousimies-Somer HR, Savolainen S, Ylikoski JS. Bacteriological findings of acute maxillary sinusitis in young adults. $J$ Clin Microbiol 1988; 26: 1919-1925.

3. Evans FO, Sydnor JB, Moore WEC et al. Sinusitis of the maxillary antrum. $N$ Engl $J$ Med 1975; 293: 735-739.

4. Carenfelt C, Lundberg C, Nord CE, Wretlind B. Bacteriology of maxillary sinusitis in relation to quality of the retained secretion. Acta Otolaryngol 1978; 86: 298-302.

5. Brook I. Bacteriologic features of chronic sinusitis in children. JAMA 1981; 246: 967-969.

6. Moss RB, King VV. Management of sinusitis in cystic fibrosis by endoscopic surgery and serial antimicrobial lavage. Reduction in recurrence requiring surgery. Ant Otolaryngol Head Neck Surg 1995; 121: 566-572.

7. Brook I, Thompson DH, Frazier EH. Microbiology and management of chronic maxillary sinusitis. Arch Otolaryngol Head Neck Surg 1994; 120: 1317-1320.

8. Summanen P, Baron EJ, Citron DM, Strong CA, Wexler HM, Finegold SM. Wadsworth anaerobic bacteriology manual, 5th edn. Belmont, CA, Star Publishing Co. 1995.

9. Balows A, Hausler WJ, Herrman KL, Isenberg HD, Shadomy HJ. Manual of clinical microbiology, 5th edn. Washington, DC, American Society for Microbiology. 1991.

10. O'Callaghan $\mathrm{CH}$, Morris A, Kirby SM, Shingler AH. Novel method for detection of beta-lactamases by using a chromogenic cephalosporin substrate. Antimicrob Agents Chemother 1972; 1: 283-288. 